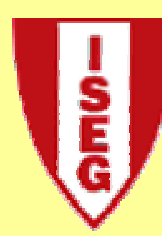

School of Economics and Management

TECHNICAL UNIVERSITY OF LISBON

Department of Economics

M. V. Ibrahimo, and Carlos Pestana Barros

Relevance or Irrelevance of Capital Structure

WP 32/2008/DE/UECE

Working Papers

ISSN Nº 0874-4548

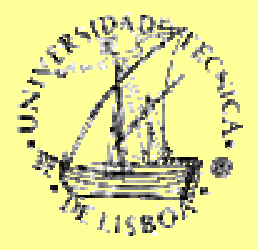




\title{
RELEVANCE OR IRRELEVANCE OF CAPITAL STRUCTURE?
}

\author{
M. V. Ibrahimo and C. P. Barros ${ }^{1}$
}

\begin{abstract}
In this paper we examine the effects of asymmetric information on the nature of financial equilibrium and on the capital structure of firms. In the first model presented, the financial contracts on offer involve pooling equilibrium with no adverse selection. However, in the special case analyzed, where contracts are of mixed form, there may be a separating equilibrium and also equilibrium may not exist. Interesting result is that the separating equilibrium found is not economically efficient since aggregate investments falls short of first-best level. More importantly, capital structure does matter. The relative magnitude of outside equity makes a real difference to the quantity of aggregate investment in equilibrium.
\end{abstract}

\section{Introduction}

In recent years a considerable effort has gone into the study of financial markets under asymmetric information in an attempt to explain the failure of those markets to engender efficient levels of investment ${ }^{2}$. In contrast with the economics of capital structure in modern corporations ${ }^{3}$, this literature has paid relatively little attention to the theoretical analysis of the effects stemming from the mixed form of financial arrangement. Optimal contracts between two parties assume either the form of debt, as in de Meza and Webb (1987), Gale and Hellwig (1985), and Williamson (1987), or the form of equity, as shown by de Meza and Webb (1987) in Stiglitz and Weiss (1981). And yet modern corporations exhibit in their capital structure both debt and equity (inside and outside). Moreover, on the theoretical level, O. Williamson (1988) shows that an optimal mix of debt and equity, which is termed «dequity», may supplant both debt and equity ${ }^{4}$. Likewise, Stiglitz notes that «these forms of financial constraints are but extreme examples, demonstrating clearly that the financial structure of 
firms can make a difference. Theories of optimal financial structure can be derived, with the optimal structure depending on the nature of the information problem being faced» (1988, p. 124). Inspired by the works of Leland and Pyle (1977) and de Meza and Webb (1990), the present study seeks to fill this lacuna by analysing a model in which a mixed form of financial contracts between financial institutions and firms is possible.

The structure of information plays a crucial role in the model. The main goal of the present analysis is to examine the effects of incomplete information and of the capital structure of firms on the nature of financial equilibrium. In addition, the study endeavours to show that the results derived in the literature of credit markets are not robust to changes in model specifications. It aims at contributing to the advance of the economics of credit markets by offering further insights.

The structure of the model is defined in section 2. The context is a simple one-period partial equilibrium model with informational asymmetries. In the model, entrepreneurs are considered to behave in a risk-averse manner and each of them is endowed with a project at the beginning of the period. The projects, if undertaken, require outside finance from risk-neutral bankers, who offer financial contracts to entrepreneurs. All projects are assumed to have the same expected return and are divided into two types: one with a high probability of securing the successful return and a second with a low probability. The quality of an individual entrepreneur's project, that is, the success probability - not known by the financial institutions - is private information. The generalisation of the analysis to continuous categories of entrepreneurs is discussed in the conclusion.

Section 3 develops the model established. If negative incentive effects are not considered, the financial equilibrium involves pooling equilibrium with both categories of projects being entirely financed through outside equity. With this type of solution there can be no adverse selection and social efficiency is achieved. Indeed, if the capital structure of firms is wholly absorbed by outside equity, all projects will be equally attractive to risk-neutral financiers. 
A special case is investigated in section 4 . The assumption that equity contract entails no cost seems unreasonable because of moral hazard problems. Incentive effects may justify an optimal small proportion of outside equity in the capital structure of firms ${ }^{5}$. It is therefore assumed that in all projects the share of equity held by outside investors is fixed and relatively small. With this assumption and no all debt finance, the model exhibits interesting properties. The first conclusion of this section is that if the equilibrium separating contract is dominant - as defined in the paper - in a set of contracts on offer, it will necessarily be the unique equilibrium. Thus, there cannot be a pooling equilibrium. However, under quite plausible conditions equilibrium may not exist, as in Rothschild and Stiglitz (1976).

The second conclusion is that credit rationing, as defined in Stiglitz and Weiss (1981), is not viable. This result is consistent with that of Bester (1985), although in a different setting. The model need not use collateral requirements to induce entrepreneurs to selfselect themselves into categories and make rationing impracticable.

The third conclusion refers to welfare properties. The competitive equilibrium is not economically efficient. As in Rothschild and Stiglitz, there is a dissipative externality, i.e. the existence of the high-risk investors produces a negative effect on the low-risk investors. But more importantly, in separating equilibrium, aggregate investment falls short of the first-best level and thus a subsidy on bank financing leads to a Pareto improvement.

Finally, capital structure of firms does matter. In disagreement with Modigliani and Miller (1958), the relative magnitude of outside equity makes a real difference to the quantity of aggregate investment in equilibrium. And interestingly, as in Harris and Raviv (1991) and Ross (1977), the leverage of firm is positively associated with default probability. Section 5 offers some concluding comments.

\section{A model of investment finance}

The context is a simple one-period partial equilibrium model with informational 
asymmetries between financial institutions and entrepreneurs. The analysis is intended to decipher the nature of equilibrium and the causes of capital market failures.

The basic assumptions of the model as well as the behaviour and objectives of economic agents are indicated below. Entrepreneurs' projects differ in risk and the problem analysed is that of financing them by own equity, debt and outside equity; this framework draws on and synthesises the works of Leland and Pyle (1977), de Meza and Webb (1990) and Stiglitz and Weiss (1981).

Consider a capital market in which there are two classes of economic agents: potential entrepreneurs who are in need of finance and banks that make it available. Entrepreneurs are risk-averse, expected utility maximisers, all with identical quasi-concave utility function of end of period wealth, $U$ (.). They each have the same initial wealth, $\mathrm{W}_{0}$, which can be invested either in an indivisible amount of investment, denoted by $\mathrm{K}$, or in a safe asset yielding the same interest rate $\rho$. For the sake of simplicity, it is assumed that deposit is the unique safe asset in the market, so if projects are not carried out, $\mathrm{W}_{0}$ is deposited with banks. The ith project, if executed, yields a random return $R_{i}$ of $R_{i}^{s}$ if it succeeds and $R_{i}^{f}$ if it fails. Adaptation of the mean preserving spread criterion of Rothschild and Stiglitz (1970) implies that all projects have a common expected gross return $\mu$ :

$$
p_{i}\left(R_{i}^{s}\right) R_{i}^{s}+\left[1-p_{i}\left(R_{i}^{s}\right)\right] R_{i}^{f}=a \text { constant, for all } i
$$

where $p_{i}$, defined in $[0,1]$, is the success probability of the ith project. Without any loss of generality, consider that $\mathrm{R}_{\mathrm{i}}^{\mathrm{f}}=\mathrm{R}^{\mathrm{f}}$ for all $\mathrm{i}$. Projects differ in risk and since $\mathrm{p}_{\mathrm{i}}$ depends on $\mathrm{R}_{\mathrm{i}}^{\mathrm{s}}$, they consequently differ in successful return. In the present analysis it is enough to assume only two categories of entrepreneurs ${ }^{6}$ : high-risk individuals with success probability $\mathrm{p}_{\mathrm{H}}\left(\mathrm{R}_{\mathrm{H}}^{\mathrm{s}}\right)$ and low-risk individuals with success probability $p_{L}\left(R_{L}{ }^{s}\right)>p_{H}\left(R_{H}{ }^{s}\right)$. This condition with (1) implies that projects are ranked by the mean preserving spread criterion. In what follows the subscript $i$ will denote the entrepreneur's category. 
To cause the need for the outside finance it is assumed that $\mathrm{W}_{0}<\mathrm{K}$, so if a project is to be carried into execution additional finance must be raised. This is done through the issuance of outside equity and/or debt securities. Debt security of current value B pays in the successful state an amount $\mathrm{D}=(1+\mathrm{r}) \mathrm{B}$, where $\mathrm{r}$ is the posted loan rate, or else pays the entire project return to the bank in the event of bankruptcy. Then the return on debt is $\min \left(D, R^{j}\right)$, and the return on equity is $\max \left(R^{j}-D, 0\right)$, where $j=s, f$. The proportion of inside equity in the project is $0 \leq \alpha \leq 1$, which is held by the entrepreneur, and the remainder - the outside equity — is sold to a bank. For the acquisition of debt security with face value of repayment D and the proportion (1 $\alpha$ ) of the equity, the bank agrees to pay a value F.

Successful states must reward both entrepreneurs and banks. Thus, it makes sense to assume $\mathrm{R}_{\mathrm{i}}^{\mathrm{s}}>\mathrm{D}$. If a project of category $\mathrm{i}$ is successful, the entrepreneur end of period wealth is:

$$
\mathrm{W}_{\mathrm{i}}^{\mathrm{s}}=\alpha\left(\mathrm{R}_{\mathrm{i}}^{\mathrm{s}}-\mathrm{D}\right)+(1+\rho)\left(\mathrm{F}+\mathrm{W}_{0}-\mathrm{K}\right)
$$

and in the low state he obtains ${ }^{7}$ :

$$
W_{i}^{f}=W^{f}=\alpha\left[\max \left(R^{f}-D, 0\right)\right]+(1+\rho)\left(F+W_{0}-K\right) .
$$

From the expected utility theorem, the entrepreneur's preferences for income in the two states of nature are described by the following function ${ }^{8}$ :

$$
E U\left(W_{i}\right)=p_{i} U\left(W_{i}^{s}\right)+\left(1-p_{i}\right) U\left(W^{f}\right), i=H, L
$$

The entrepreneur of category i will execute his project if:

$$
\mathrm{EU}\left(\mathrm{W}_{\mathrm{i}}\right) \geq \mathrm{U}\left[(1+\rho) \mathrm{W}_{0}\right]
$$


A group of few large banks supply finance. They are assumed to be competitive, risk-neutral expected profit maximisers. Competition is of Bertrand type in price strategies. Banks pay for each unit of deposits the interest rate $\rho$; other costs as well as activities of banking are neglected. The supply of funds to a bank is assumed to be non-decreasing in the safe rate of interest, $\rho$. Given the partial equilibrium nature of the model, this relationship is given exogenously and thus not derived from first principles. It is assumed that banks have knowledge about the proportion of each of the two categories of entrepreneurs, $\lambda_{\mathrm{i}} \in[0,1]$, with $\lambda_{\mathrm{L}}+\lambda_{\mathrm{H}}=1$. Furthermore, they know the success probability $\mathrm{p}_{\mathrm{i}}$ of each type. However, banks cannot distinguish ex ante the characteristics of each entrepreneur's project. This assumption introduces the key asymmetry of information into the model. The ex post return of each project once executed is assumed to be observable without cost to both bank and entrepreneur. When finance is made available, the financial contract specifies its terms F, $\alpha$ and D. With this contract offered to an entrepreneur of category i, in the successful state the bank makes a profit of:

$$
\pi_{\mathrm{Bi}}^{\mathrm{s}}=\mathrm{D}+(1-\alpha)\left(\mathrm{R}_{\mathrm{i}}^{\mathrm{s}}-\mathrm{D}\right)-(1+\rho) \mathrm{F}, \mathrm{i}=\mathrm{H}, \mathrm{L}
$$

and in the low state:

$$
\pi_{B i}^{f}=\pi_{B}^{f}=\min \left(D, R^{f}\right)+(1-\alpha) \max \left(R^{f}-D, 0\right)-(1+\rho) F
$$

where $R^{f}$ can be greater or smaller than $D$. Thus, the expected profit to the bank from a project of category $i$ and the above contract is:

$$
\mathrm{E}\left(\pi_{\mathrm{Bi}}\right)=\mathrm{p}_{\mathrm{i}} \pi_{\mathrm{Bi}}^{\mathrm{s}}+\left(1-\mathrm{p}_{\mathrm{i}}\right) \pi_{\mathrm{B}}^{\mathrm{f}}
$$

where $p_{i}=p_{i}\left(R_{i}^{s}\right)$. 
In the present study, coalition between agents is ruled out and each entrepreneur can only carry out one project.

The following definition is now introduced.

Definition 1: Equilibrium in the competitive capital market is a set of financial contracts such that all contracts in the equilibrium set yield zero expected profit to banks; and there exists no other contract in the exterior of the equilibrium set which — if offered — generates a non-negative expected profit.

Definition 1 implies a Bertrand competition. Each bank expects that the rivals will keep the terms of financial contracts invariable, irrespective of its own decisions.

The next section develops the model here established and the properties of the market equilibrium are inspected ${ }^{9}$.

\section{Financial equilibrium in the model}

The interpretation of (1) is that projects differ according to the mean preserving spread criterion: all projects are assumed to have the same expected value, but riskier projects have a larger variance in returns than less risky ones (see Stiglitz and Weiss, 1981). This section shows that, under some conditions, the properties of equilibrium in capital markets with asymmetric information may not differ from those of complete information.

Bertrand competition implies that (8) must equal zero in a manner corresponding to the explanation given below. This condition yields the following equation for the offer of financial contracts in $\left(\mathrm{W}^{\mathrm{f}}, \mathrm{W}^{\mathrm{s}}\right)$ space:

$$
\mathrm{W}_{\mathrm{i}}^{\mathrm{s}}=-\left[\left(1-\mathrm{p}_{\mathrm{i}}\right) / \mathrm{p}_{\mathrm{i}}\right] \mathrm{W}_{\mathrm{i}}^{\mathrm{f}}+\left(1 / \mathrm{p}_{\mathrm{i}}\right)\left[\mu+(1+\rho)\left(\mathrm{W}_{0}-\mathrm{K}\right)\right]
$$


where $\mathrm{p}_{\mathrm{i}}$ depends on $\mathrm{R}_{\mathrm{i}}^{\mathrm{s}}$ which is given for each entrepreneurs' category. The slope of an offer curve is given by $-\left(1-\mathrm{p}_{\mathrm{i}}\right) / \mathrm{p}_{\mathrm{i}}$ and, clearly, is steeper for the riskier category. The second term on the right hand side of (9) is positive since $\mu>(1+\rho)\left(\mathrm{K}-\mathrm{W}_{0}\right)$, otherwise projects would not be financed.

Let the subscript A denote an «abstract» average category of entrepreneurs; and let $\mathrm{p}_{\mathrm{A}}=\lambda_{\mathrm{L}} \mathrm{p}_{\mathrm{L}}+\left(1-\lambda_{\mathrm{L}}\right) \mathrm{p}_{\mathrm{H}}$ be the success probability of category $\mathrm{A}$ entrepreneurs. Then substituting $\mathrm{p}_{\mathrm{A}}$ for $\mathrm{p}_{\mathrm{i}}$ in (9), an average-risk offer locus is obtained, where a bank earns zero expected profit on average. The average-offer curve can be thought of as a benchmark to locate pooling contracts in $\left(\mathrm{W}^{\mathrm{f}}, \mathrm{W}^{\mathrm{s}}\right)$ space.

\section{Insert Figure 1}

Figure 1 shows the offer lines $\mathrm{O}_{\mathrm{H}}, \mathrm{O}_{\mathrm{A}}$ and $\mathrm{O}_{\mathrm{L}}$ derived from (8) with $\mathrm{i}=\mathrm{H}, \mathrm{A}, \mathrm{L}$, respectively. The three lines cross the certainty line at the same point, since when $\alpha=0$ all projects are equally attractive for risk-neutral bankers who are willing to pay to all entrepreneurs the same actuarially fair price in both states. Consider the offer locus $\mathrm{O}_{\mathrm{H}}$. From (2), (3) and (9), at point E, $\alpha=0, \mathrm{D}_{\mathrm{H}}=0$ and $\mathrm{F}_{\mathrm{H}}>\mathrm{K}-\mathrm{W}_{0} \cdot \mathrm{W}_{\mathrm{H}}^{\mathrm{s}}$ is maximised if $\mathrm{W}_{\mathrm{H}}^{\mathrm{f}}=0$, which implies $\mathrm{F}_{\mathrm{H}}=\mathrm{K}-\mathrm{W}_{0}$ and $\mathrm{D}_{\mathrm{H}} \geq \mathrm{R}^{\mathrm{f}}$. Thus, the payoff at $B$ can be sustained with many combinations of $\alpha_{H}$ and $D_{H}$, one of which is all debt security finance, i. e. $\alpha_{H}=1$. On the interior of the locus, $\alpha_{H}, D_{H}$ and $\mathrm{F}_{\mathrm{H}}$ vary, but $\mathrm{F}_{\mathrm{H}}$ must always be greater than or equal to $\mathrm{K}-\mathrm{W}_{0}$, otherwise projects cannot be carried out.

Consider now a financial contract, denoted by $\left(\mathrm{F}^{*}, \alpha^{*}, \mathrm{D}^{*}\right)$, on which a bank earns on average zero expected profit. The contract $\left(\mathrm{F}^{*}, \alpha^{*}, \mathrm{D}^{*}\right)$ must then lie on the $\mathrm{O}_{\mathrm{A}}$ locus - for instance at $\mathrm{A}$ in figure 1 - if offered to a hypothetical average-risk entrepreneur. This contract, however, may or may not yield a nonzero expected profit if offered to either a high- or low-risk entrepreneur. Notice that in (2) and (3) $\mathrm{R}_{\mathrm{H}}^{\mathrm{S}}>\mathrm{R}_{\mathrm{L}}^{\mathrm{S}}$ and 
$\mathrm{R}_{\mathrm{H}}^{\mathrm{f}}=\mathrm{R}_{\mathrm{L}}^{\mathrm{f}}$. Thus, the contract $\left(\mathrm{F}^{*}, \alpha^{*}, \mathrm{D}^{*}\right)$ lies - on the vertical line through $\mathrm{W}_{1}^{\mathrm{f}}$ as shown in figure 1 - above $\mathrm{A}$ if offered to a high-risk entrepreneur and below this point if offered to a low-risk one. Whether or not $\left(\mathrm{F}^{*}, \alpha^{*}, \mathrm{D}^{*}\right)$ lies on the high- and lowrisk offer curves will depend upon the value of $\alpha^{*}$, as will be shown below.

Suppose that both categories of entrepreneurs choose the contract $\left(\mathrm{F}^{*}, \alpha^{*}, \mathrm{D}^{*}\right)$. Then $\mathrm{W}_{\mathrm{H}}^{\mathrm{f}}=\mathrm{W}_{\mathrm{L}}^{\mathrm{f}}=\mathrm{W}^{\mathrm{f}}$ and from (2) it follows that:

$$
\mathrm{W}_{\mathrm{H}}^{\mathrm{S}}-\mathrm{W}_{\mathrm{L}}^{\mathrm{S}}=\alpha^{*}\left(\mathrm{R}_{\mathrm{H}}^{\mathrm{S}}-\mathrm{R}_{\mathrm{L}}^{\mathrm{S}}\right)=\alpha *\left(\mu-\mathrm{R}_{\mathrm{f}}\right)\left[\left(\rho_{\mathrm{L}}-\rho_{\mathrm{H}}\right) / \rho_{\mathrm{H}} \rho_{\mathrm{L}}\right] \geq 0
$$

But from (9), along the offer curves (e. g. comparing $\mathrm{H}$ and $\mathrm{L}$ in figure 1):

$$
\mathrm{W}_{\mathrm{H}}^{\mathrm{S}}-\mathrm{W}_{\mathrm{L}}^{\mathrm{S}}=\left[-\mathrm{W}^{\mathrm{f}}+\mu+(1+\rho)\left(\mathrm{W}_{0}-\mathrm{K}\right)\right]\left[\left(\rho_{\mathrm{L}}-\rho_{\mathrm{H}}\right) / \rho_{\mathrm{H}} \rho_{\mathrm{L}}\right] \geq 0
$$

where $\mathrm{W}^{\mathrm{f}} \leq \mu+(1+\rho)\left(\mathrm{W}_{0}-\mathrm{K}\right)$. The values of the difference $\mathrm{W}_{\mathrm{H}}^{\mathrm{S}}-\mathrm{W}_{\mathrm{L}}^{\mathrm{S}}$ in (10) and (11) need not be equal since the following may hold:

$$
\alpha^{*} \leq \text { or }>\left[-\mathrm{W}^{\mathrm{f}}+\mu+(1+\rho)\left(\mathrm{W}_{0}-\mathrm{K}\right)\right] /\left(\mu-\mathrm{R}^{\mathrm{f}}\right)
$$

in which by assumption $\mathrm{R}^{\mathrm{f}}<(1+\rho)\left(\mathrm{K}-\mathrm{W}_{0}\right)^{10}$. To simplify the description of (12), let $\left[-\mathrm{W}^{\mathrm{f}}+\mu+(1+\rho)\left(\mathrm{W}_{0}-\mathrm{K}\right)\right] /\left(\mu-\mathrm{R}^{\mathrm{f}}\right)$ be $\varphi$. As a result of $(12)$, three cases may occur. When $\alpha^{*}=\varphi,(10)$ equals $(11)$ and therefore the contract $\left(\mathrm{F}^{*}, \alpha^{*}, \mathrm{D}^{*}\right)$ which yields on average zero expected profit will also yield zero expected profit with each category. Thus, in this case, a risk-neutral bank looks indifferently at both categories of projects, since from the bank's viewpoint the low risk-projects are as profitable as the high-risk ones. The reason is that the relative amount of outside equity in projects is large enough to overcome the conflict of interests - stemming from the issuance of debt security - between bankers and entrepreneurs. An example of the present case is shown in figure 1 , where a given contract $\left(\mathrm{F}^{*}, \alpha^{*}, \mathrm{D}^{*}\right)$ is at $\mathrm{H}$ and $\mathrm{L}$ 
for the high- and low-risk groups respectively. But from the earlier discussion, if $\alpha^{*}=0$, then $\mathrm{W}_{\mathrm{i}}^{\mathrm{S}}=\mathrm{W}^{\mathrm{f}}=\mu+(1+\rho)\left(\mathrm{W}_{0}-\mathrm{K}\right)$ and, therefore, $\left(\mathrm{F}^{*}, \alpha^{*}, \mathrm{D}^{*}\right)$ will be at point $\mathrm{E}$ for both groups.

Using similar reasoning, it can easily be shown that if $\alpha^{*}<\varphi,\left(\mathrm{F}^{*}, \alpha^{*}, \mathrm{D}^{*}\right)$ will cause negative expected profit with category $L$ entrepreneurs and positive expected profit with category $\mathrm{H}$ entrepreneurs. Thus, given a financial contract in which the proportion of outside equity is relatively large, riskier projects are the more profitable ones for banks. In figure $1\left(\mathrm{~F}^{*}, \alpha^{*}, \mathrm{D}^{*}\right)$ must be below point $\mathrm{H}$ and above point $\mathrm{A}$ for the high-risk group, and above $\mathrm{L}$ and below A for the low-risk group.

The preferences of banks about project categories depend not only upon the nature of intermediation but depend also on the ownership structure of firms. The nature of financial contracts thus provides the rationale for the above results which are in contrast with the Stiglitz and Weiss (1981) theorem that banks prefer less risky projects. This type of behaviour is not, however, ruled out in the present study, since whenever $\alpha^{*}>\varphi$, riskier projects yield a lower expected profit for a bank. In figure 1, if the value of outside equity is relatively small $\left(\mathrm{F}^{*}, \alpha^{*}, \mathrm{D}^{*}\right)$ must then lie above point $\mathrm{H}$ for the high-risk category and below point $\mathrm{L}$ for the low-risk one. Also notice that all debt security finance $\left(\alpha^{*}=1\right)$ is an example of the present case. Implications of the special case $1>\alpha^{*}>\varphi$ are set out in the next section.

Indifference curves of risk-averse entrepreneurs are derived from (4) and it is easy to verify that these curves are strictly convex and steeper, at any point to the left of the certainty line, for riskier projects. Moreover, indifference curves of each category are steeper than the respective bank's offer curve at any feasible contract $\left(\mathrm{F}^{*}, \alpha^{*}, \mathrm{D}^{*}\right)$. To save space, these curves are not here shown graphically.

The following proposition is now established.

Proposition 1: Assume that all categories of projects in a capital market have a common 
expected return but each one has different dispersion of returns. Moreover, assume that banks cannot ascertain the riskiness of a project category. Then there exists a unique equilibrium such that: (i) a pooling contract is signed with $\alpha^{*}=0, \mathrm{D}^{*}=0$ and $\mathrm{F}^{*}=$ $\mu /(1+\rho)$; and (ii) social efficiency in aggregate investment is achieved.

The proof of this is given in Ibrahimo (1993). The implication of the Proposition 1 is that with all outside equity finance each entrepreneur receives - in both states - the same actuarially fair payoff which equals $\mu+(1+\rho)\left(\mathrm{W}_{0}-\mathrm{K}\right)$. In equilibrium this payoff must be equal to $(1+\rho) \mathrm{W}_{0}$ and $\mu+(1+\rho) \mathrm{K}$ for all categories of projects. That is to say, at the margin banks finance the marginal socially optimal investment. The intuitive explanation of the optimality of the equity-based contract is straightforward. When both categories of projects are entirely financed through outside equity their risk characteristic is irrelevant and, hence, they are equally attractive to risk-neutral financiers. As a consequence, in equilibrium there is no adverse selection problem and credit rationing is not viable.

Not surprisingly, Proposition 1 mirrors the results found by de Meza and Webb (1987) in the Stiglitz and Weiss (1981) model, where both entrepreneurs and bankers are riskneutral. Thus, the possibility of under-investment with all debt finance, noted by de Meza and Webb (1987) and Hillier and Ibrahimo (1992), is ruled out in the present case under efficient equity-based intermediation. However, Stiglitz and Weiss would, of course, refer to moral hazard problems in equity markets and predict a mixed form of finance. In fact, the conjecture that the outside equity issue does not entail costs sounds illogical because of adverse incentive effects. As a matter of fact, too little effort may be invested by managers in the governance of firms if the share of outside financiers in the capital structure is relatively large. Monitoring of managerial performance could be implemented to reduce the extent to which that inefficiency occurs, but this would itself be costly. Thus, there must exist an optimal proportion of outside equity relative to debt which provides proper incentives for entrepreneurs. The reason for this will be further discussed in the next section, where, as a consequence, the proportion of inside equity, $\alpha$, is considered exogenously fixed and relatively large but smaller than one. The assumption imposed on the form 
of financial contracts is obviously less adequate than if it were derived from the first principles, but, as will be seen, it does provide some interesting insights. Moreover, by considering $\alpha$ relatively large, comparison with the Stiglitz and Weiss model will make more sense.

\section{Mixed form of finance}

The literature of financial markets with asymmetric information, with few exceptions, treats debt and equity as extreme alternative means of finance. This is so because optimal contracts are derived under very restrictive assumptions. For instance, in the previous section equity is the optimal financial arrangement if the adverse incentive effects arising from the actions of managers are not taken into account. On this matter, it does seem that the theory of the capital structure of modern corporations uses an approach more consistent with the real world. For example, Jensen and Meckling contend that, in entrepreneurial firms where the resources of entrepreneurs are limited, projects are not in general entirely financed through outside equity, since the entrepreneur's incentives would be diluted. The answer to the question of why not to support them with debt up to the hilt turns on "(1) the incentive effects associated with highly levered firms; (2) the monitoring costs these effects engender; and (3) bankruptcy costs" (1976, p. 334). In other words, all debt finance could induce entrepreneurs to take very large ex post risks, knowing that proper penalties would not accrue to debt holders in the case of bankruptcy and gains would be captured by entrepreneurs if projects are successful. As perceptive financiers will see through this risk and impose a premium, debt security will become available on progressively worse terms. Thus, an optimal combination of debt and equity can be obtained if the effects of adverse incentives - from issuing new equity — and risk distortions - from issuing debt - are equalised at the margin. It is also for this reason that in O. Williamson (1988) a combined use of debt and equity in the financed investment projects may be optimal. It does, therefore, seem useful to study the effects of dequity in the present framework ${ }^{11}$. 
Here a special combination of debt and equity is considered. In all financial contracts, let $\alpha$ be fixed and greater than $\varphi$, i.e. $\alpha=\bar{\alpha}>\varphi^{12}$. This allows a clearer comparison with the Stiglitz and Weiss model. Thus, as noted before, if $\bar{\alpha}>\varphi$, riskier projects yield a lower expected profit for banks. And let $D_{\max }$ be the maximum amount of debt allowed for both categories of entrepreneurs. Then the assumptions of the model imply that, if finance is supplied, $\mathrm{D} \leq \mathrm{D}_{\max }<\mathrm{R}_{\mathrm{L}}^{\mathrm{S}}<\mathrm{R}_{\mathrm{H}}^{\mathrm{S}}$. Assume also that $0<\mathrm{R}^{\mathrm{f}}<\mathrm{D}$. Now, for a given contract $\left(\mathrm{F}^{*}, \alpha^{*}, \mathrm{D}^{*}\right)$ equations (2) and (3) become:

$$
\begin{aligned}
& \mathrm{W}_{\mathrm{i}}^{\mathrm{S}}=\bar{\alpha}\left(\mathrm{R}_{\mathrm{i}}^{\mathrm{s}}-\mathrm{D}+(1+\rho)\left(\mathrm{F}+\mathrm{W}_{0}-\mathrm{K}\right),\right. \\
& \mathrm{W}_{\mathrm{i}}^{\mathrm{f}}=\mathrm{W}^{\mathrm{f}}=(1+\rho)\left(\mathrm{F}+\mathrm{W}_{0}-\mathrm{K}\right)
\end{aligned}
$$

and equations (6) and (7) become:

$$
\begin{gathered}
\pi_{\mathrm{Bi}}^{\mathrm{S}}=\mathrm{D}+(1-\bar{\alpha})\left(\mathrm{R}_{\mathrm{i}}^{\mathrm{s}}-\mathrm{D}\right)-(1+\rho) \mathrm{F} \\
\pi_{\mathrm{Bi}}^{\mathrm{f}}=\pi_{\mathrm{B}}^{\mathrm{f}}=\mathrm{R}^{\mathrm{f}}-(1+\rho) \mathrm{F} .
\end{gathered}
$$

In equilibrium (8) must equal zero, for a separating equilibrium if $\mathrm{i}=\mathrm{H}, \mathrm{L}$, and for a pooling equilibrium if $\mathrm{i}=\mathrm{A}$. Using (13), (14), (15) and (16) in the zero expected profit condition, the expression for the offer curves is obtained in $(F, D)$ space:

$$
\mathrm{D}=\left[(1+\rho) / \mathrm{p}_{\mathrm{i}} \bar{\alpha}\right] \mathrm{F}+\mathrm{R}_{\mathrm{i}}^{\mathrm{S}}-\mu / \mathrm{p}_{\mathrm{i}} \bar{\alpha}
$$

with slope $(1+\rho) / \mathrm{p}_{\mathrm{i}} a$ which clearly is steeper for the riskier category. If $\mathrm{p}_{\mathrm{i}}=\mathrm{p}_{\mathrm{A}}=\lambda_{\mathrm{L}} \mathrm{p}_{\mathrm{L}}+\left(1-\lambda_{\mathrm{L}}\right) \mathrm{p}_{\mathrm{H}}$ and $\mathrm{R}_{\mathrm{i}}^{\mathrm{S}}=\mathrm{R}_{\mathrm{A}}^{\mathrm{S}}$, (17) will define the pooling offer curve. Figure 2 illustrates the lines $\mathrm{O}_{\mathrm{H}}, \mathrm{O}_{\mathrm{A}}$ and $\mathrm{O}_{\mathrm{L}}$ which are the offer curves with $\mathrm{i}=$ $\mathrm{H}, \mathrm{A}, \mathrm{L}$, respectively. Consider the line $\mathrm{O}_{\mathrm{H}}$. Contracts on offer lying above (below) this line, if selected by the high-risk entrepreneurs, will cause positive (negative) 
expected profit for banks.

Substitution of (13) and (14) for $\mathrm{W}_{\mathrm{i}}^{\mathrm{S}}$ and $\mathrm{W}^{\mathrm{f}}$ into (4) implies the following relationship for indifference curves:

$$
\begin{aligned}
& \mathrm{p}_{\mathrm{i}} \mathrm{U}\left[\bar{\alpha}\left(\mathrm{R}_{\mathrm{i}}^{\mathrm{S}}-\mathrm{D}\right)+(1+\rho)\left(\mathrm{F}+\mathrm{W}_{0}-\mathrm{K}\right)\right]+ \\
& +\left(1+\mathrm{p}_{\mathrm{i}}\right) \mathrm{U}\left[(1+\rho)\left(\mathrm{F}+\mathrm{W}_{0}-\mathrm{K}\right)\right]=\overline{\mathrm{u}}
\end{aligned}
$$

where $\overline{\mathrm{u}}$ is a constant and denotes a utility level. It can easily be shown that these curves are concave and steeper, at any point (F, D), for the riskier projects, as shown in figure 2 where $I_{H}$, and $I_{L}$ are the indifference curves for the highand low-risk individuals, respectively. Moreover, indifference curves of each category are steeper, at any contract (F, D), than the respective bank's offer curve. The following lemma is useful in restricting the value of $\alpha$ within particular limits which will provide the derivation of interesting results in the present model.

Lemma 1: There is an interval of $\bar{\alpha}$ such that $\bar{\alpha}>\varphi$ and $\mathrm{F}>\mathrm{K}-\mathrm{W}_{0}$ for all the feasible financial contracts on offer.

The proof of this is straightforward. Suppose that $\mathrm{F}>\mathrm{K}-\mathrm{W}_{0}$. From this it follows that $\left.\left[\varphi \mathrm{R}^{\mathrm{f}}+(1-\varphi) \mu\right)\right] /(1+\rho)>\mathrm{K}-\mathrm{W}_{0}$. Hence, there is an interval of $\alpha$ near $\varphi$ where $\mathrm{F}>\mathrm{K}-\mathrm{W}_{0}$ for all possible contracts on offer.

In what follows it is assumed that the value of $\bar{\alpha}$ is within the limits of the interval defined by Lemma 1 . That is to say, in figure $2, F=K-W$ must lie to the left of point $E$. Thus, in the present framework, all debt contract is not viable, since $R^{\mathrm{f}}<(1$ $+\rho)\left(\mathrm{F}+\mathrm{W}_{0}\right)$ by assumption. So it must be $1>\bar{\alpha}>\varphi$.

The equilibrium solution under complete information - which will provide a benchmark against which to measure the effects of asymmetric information - is now 
derived. This solution follows immediately upon observing that the expected utility of each category increases as its respective indifference curve moves rightwards in figure 2. Equilibrium with no private information is therefore achieved with the pair of separating contracts $(\mathrm{A}, \mathrm{C})$, where the contract $\mathrm{A}$ is selected by the high-risk group and $\mathrm{C}$ by the low-risk one.

Insert Figure 2

Next, equilibria in the model with incomplete information are discussed. For expositional convenience, the following definition is advanced.

Definition 2: Let $\mathrm{v}_{\mathrm{H}}$ and $\mathrm{v}_{\mathrm{L}}$ be contracts selected by the high- and low-risk entrepreneurs, respectively. If they involve equilibrium and cannot be displaced by any other contract on offer, then $\mathrm{v}_{\mathrm{H}}$ and $\mathrm{v}_{\mathrm{L}}$ are said to be dominant contracts.

Obviously, definition 2 requires incentive compatibility between banks and entrepreneurs. When $\mathrm{v}_{\mathrm{H}}=\mathrm{v}_{\mathrm{L}}$, equilibrium will be settled through a pooling contract, and with $\mathrm{v}_{\mathrm{H}} \neq \mathrm{v}_{\mathrm{L}}$ through separating contracts.

Now a simple argument establishes the following proposition.

Proposition 2: Consider the assumptions of the model with $\alpha=\bar{\alpha}>\varphi$ Then a pooling equilibrium cannot exist.

It is easy to prove this proposition with the help of figure 3 below. Suppose that $\mathrm{P}$ is a pooling equilibrium. Since $\mathrm{P}$ lies on the $\mathrm{O}_{\mathrm{A}}$ line, the offering bank makes on average zero expected profit. At this point, the slope of the high-risk indifference curve, $I_{H}$, is steeper than the low-risk indifference curve, $I_{L}$. Thus there is a contract - for instance $\gamma$ - in the neighbourhood of P which low-risk entrepreneurs prefer to P. Obviously, the high-risk group prefers $\mathrm{P}$ to $\gamma$. Since the contract $\gamma$ attracts the less risky group, it earns the offering bank a positive expected profit. The existence of $\gamma$ 
contradicts the definition of the equilibrium. Hence, the pooling contract $\mathrm{P}$ cannot be equilibrium. And at all events, a pooling equilibrium contract at any point along the offer curve $\mathrm{O}_{\mathrm{A}}$ is impossible because the indifference curve of the high-risk group is steeper than that of the low-risk one at any contract (F, D). As a result of this, contract such as $\gamma$ will always exist ${ }^{13}$.

\section{Insert Figure 3}

The following proposition may now be advanced.

Proposition 3: Under the assumptions of the model, if equilibrium exists then it must be established through a pair of separating contracts.

This follows from figure 4. As shown previously, the contract on the $\mathrm{O}_{\mathrm{H}}$ line most preferred by category $\mathrm{H}$ entrepreneurs is at A, which must be part of equilibrium. On the $\mathrm{O}_{\mathrm{L}}$ line the most preferred contract by the L category is at C. However, the pair of contracts $\mathrm{A}$ and $\mathrm{C}$ cannot be a separating equilibrium because of the nature of incomplete information which makes banks unable to distinguish the characteristics of entrepreneurs. Notice that contract $\mathrm{C}$ would attract both high- and low-risk groups and so banks would make negative expected profit. Then an equilibrium contract for the $\mathrm{L}$ category must lie on the $\mathrm{I}_{\mathrm{H} 1}$ locus. It is clear that on this curve, of contracts $\mathrm{A}$ and $\mathrm{S}$, the one most preferred by the low-risk entrepreneurs is at S. Hence, the pair (A, S) — being dominant in the set of all contracts on offer - is the only possible equilibrium in the market.

\section{Insert Figure 4}

The following proposition — which may be seen as a corollary of Proposition 2 deals with the non-existence of equilibrium.

Proposition 4: Under the assumptions of the model and for some configuration of 
$\lambda_{L}, p_{L}, p_{H}$ and level of risk aversion, the competitive financial market may have no equilibrium.

The proof of this is as follows. Suppose the values of $\lambda_{L}, p_{L}, p_{H}$ and the level of risk aversion are such that the format of curves is the same as in figure 3. In this event, note first that the pair of separating contracts $(\mathrm{A}, \mathrm{S})$ cannot be an equilibrium since the pooling contract $\mathrm{P}$ dominates - in the sense of Definition 2 - those contracts. Indeed, in figure 3 both categories of entrepreneurs prefer $\mathrm{P}$ to $(\mathrm{A}, \mathrm{S})^{14}$. Then the unique candidate for the equilibrium is the pooling contract P. But from Proposition 2 it follows that contract $\mathrm{P}$ cannot be equilibrium. Hence, in this case there is no equilibrium.

Note that the possibility of non-existence of pure strategy equilibrium in this framework is analogous to the non-existence case of Rothschild and Stiglitz (1976). It is obvious that proposition 4 is a consequence of a given configuration of $\lambda_{L}, p_{L}, p_{H}$ and level of risk-aversion. In fact, equilibrium will not exist if there is a contract like $\gamma$ in figure 3, and note that $\gamma$ 's profitability will depend upon the composition of the entrepreneurs' population; $\gamma$ will make positive expected profit if $\lambda_{L}$ is large enough and $\mathrm{p}_{\mathrm{A}}$ close enough to $\mathrm{p}_{\mathrm{L}}$. It is therefore possible to conclude that an equilibrium will not exist if the subsidies transferred to high-risk individuals in pooling contracts are low, or if the costs to low-risk individuals in separating contracts are relative excessive.

The possibility of equilibrium credit (and equity) rationing has been highlighted in a large body of literature on asymmetric information, notable early examples being Jaffee and Russell (1976), Keeton (1979) and Stiglitz and Weiss (1981). Rationing in these models arises because of adverse selection and/or moral hazard effects. Adverse selection is not ruled out in the present model. Despite this, in the present framework credit-equity rationing is not viable, since rationing, as defined in Stiglitz and Weiss, is inconsistent with equilibrium defined by separating contracts ${ }^{15}$. Thus, with risk-averse entrepreneurs and risk-neutral banks a similar result to that described by Bester (1985) is obtained: in the seemingly plausible configuration of capital market here considered, if a 
separating equilibrium exists, it must be market clearing.

The analysis now turns to welfare properties of the equilibrium and policy implications. Some models of the credit market show that - from a production point of view separating equilibrium involves the first-best solution [e. g. de Meza and Webb (1990), and implicitly in Bester (1985)]. However, in contrast with this result, the following proposition is established.

Proposition 5: Consider the assumptions of the model with $\alpha=\bar{\alpha}>\varphi$ and $\mu_{\mathrm{i}}=\mu$ for all $\mathrm{i}$. Then at the competitive separating equilibrium, investment is below its respective socially efficient level.

The proof of this is rather complex and is given in Ibrahimo (1993). Its basic intuition is provided below.

The class of market here considered exhibits in equilibrium another efficiency problem. As in the Rothschild and Stiglitz model, there is a negative externality of highrisk categories on low-risk categories. The externality is purely dissipative, i. e. utilities in social terms are wasted. Comparing with the solution of perfect information, low-risk categories are worse off but high-risk categories are no better off. It is worth mentioning that this type of externality - which is due to the nature of asymmetric information - is the main cause of inefficiency that arises in the quantity of aggregate investment. In reality, the presence of high-risk entrepreneurs in the market induces low-risk entrepreneurs to demand lower amount of debt than they would if information were perfect. With a large number of entrepreneurial categories (i.e. not just two categories), since for each category a lower debt involves a lower value paid by banks in exchange for bonds (e. g. see figure 4), the categories of projects with the highest success probabilities become unprofitable from the point of view of entrepreneurs and hence are not executed. Consequently, in equilibrium the quantity of aggregate investment falls short of the first-best level.

The negative effects of high-risk entrepreneurs on low-risk ones also produce an 
inefficient risk sharing. If the level of risk borne by individuals in their projects under perfect information is considered optimal, then low-risk entrepreneurs bear too much risk with private information. The process of risk shifting from bankers to entrepreneurs, in the present case, is effected through the quantity of demand for debt. Along the offer curves, the higher the value of debt is the higher the risk borne by the banks in projects will be. Figure 4 may be used to illustrate this mechanism of risk transfer. When a project is carried out, the portfolio of assets of the entrepreneur is composed of an amount of deposit and his share a in the project. The value of deposit is $\mathrm{F}_{\mathrm{i}}+\mathrm{W}_{0}-\mathrm{K}$ and the value of endowment invested in the project is $\mathrm{W}_{0}-\left(\mathrm{F}_{\mathrm{i}}+\mathrm{W}_{0}-\mathrm{K}\right)=$ $\mathrm{K}-\mathrm{F}_{\mathrm{i}}$ Let $\mathrm{F}_{\mathrm{LC}}$ be the value paid to a low-risk entrepreneur in equilibrium if there is complete information; and let $F_{L S}$ be the value paid in equilibrium with incomplete information. In figure 4 , points $\mathrm{C}$ and $\mathrm{S}$ define these values, respectively. Thus, with complete information $\mathrm{W}_{0}=\left(\mathrm{F}_{\mathrm{LC}}+\mathrm{W}_{0}-\mathrm{K}\right)+\left(\mathrm{K}-\mathrm{F}_{\mathrm{LC}}\right)$ and with incomplete $\mathrm{W}_{0}=\left(\mathrm{F}_{\mathrm{LS}}+\mathrm{W}_{0}-\mathrm{K}\right)+\left(\mathrm{K}-\mathrm{F}_{\mathrm{LS}}\right)$. Since $\mathrm{F}_{\mathrm{LC}}>\mathrm{F}_{\mathrm{LS}}$, it is clear that with private information low-risk entrepreneurs will deposit less and invest more in projects of their initial endowment $\mathrm{W}_{0}$ than they would with complete information. Hence, low-risk entrepreneurs bear too much risk in equilibrium with private information. Note that the risk shifting to low-risk individuals is a result of the lower quantity of demand for debt as $F_{L}$ increases with $D_{L}$ along the contract curve $\mathrm{O}_{\mathrm{L}}{ }^{16}$.

The under-investment result suggests that a policy aimed at improving efficiency should encourage more investment which could be achieved by a subsidy on bank financing. It does appear, however, that such a policy must be second-best since it would not dispose of negative externality on low-risk individuals. The implementation of policies leading to a reduction of asymmetric information in the market does seem very attractive. But social benefits arising from such policies must be compared with social costs. This type of analysis is, however, beyond the scope of the present partial equilibrium one.

The present section also demonstrates that real economic decisions are not independent of the corporate financial structures. Against the conclusions resulting from the 
Modigliani-Miller proposition, it has been shown that capital structure of firms does matter. Clearly, the relative value of outside equity in the capital structure of firms produces a real difference in the level of aggregate investment in equilibrium.

Finally, as in Harris and Raviv (1991) and Ross (1977), the model of this section predicts a positive correlation between leverage and default probability, as shown in figure 4 . Firms with less risky returns will have lower debt levels. Signalling produces welfare costs by inducing low-risk entrepreneurs to take lower debt positions in their firms than they would if information could be directly transmitted.

\section{Conclusion}

A shortcoming of a number of the previous studies on financial markets under asymmetric information is that financial arrangements either take the form of debt or equity. Contrary to this view, the literature on capital structure of modern corporations considers that there may be an optimal combination of debt and outside equity in the capital structure of firms. Thus, the present study has developed a model of financial market in which dequity is the financial arrangement between financiers and entrepreneurs. If the proportion of inside equity is relatively large, an equilibrium, if it exists, is unique and entails separating contracts. Equilibrium credit rationing is not viable. A novel result is that separating equilibrium involves too little investment. A subsidy on bank financing could therefore be Pareto-improving. However, because of negative externalities due to the presence of high-risk individuals, it seems that the best a policymaker could hope for would be to achieve a second-best allocation.

In the model - letting all the terms of contract vary, but without any consideration of moral hazard problems - in the unique pooling equilibrium the capital structure of firms is entirely absorbed by the outside financiers and the first-best solution is achieved. Adverse incentive effects may, however, prevent the achievement of social efficiency.

The analysis was restricted to only two entrepreneurial categories. It may be shown, 
however, that the propositions derived are perfectly valid in the case of a continuum of entrepreneurial types. The only qualification is that projects not satisfying condition (5) would not be carried out. The boundary line below which projects are not financed would thus be derived endogenously.

Various extensions of the present analysis are possible. A natural extension would be to consider the multi-period analogue of the model, i. e. to allow entrepreneurs to invest more than once and to keep continuing relationships with intermediaries. The purpose of doing this would be to see if long-term financier-entrepreneur relationships eliminate or reduce the welfare costs. Another direction of research could be to incorporate explicitly into the analysis moral hazard problems and -derive endogenously optimal financial contracts. And empirical work is needed to identify the main features of contracts between financiers and firms. 


\section{NOTES}

${ }^{1}$ Ibrahimo and Barros are at Universidade Técnica de Lisboa, Instituto Superior de Economia e Gestão.

${ }^{2}$ For a survey of this literature see Hillier and Ibrahimo (1993).

${ }^{3}$ For a survey of the literature on capital structure of modern corporations see Harris and Raviv (1991).

${ }^{4}$ Hellmann and Stiglitz (2000) consider both equity and debt markets, however in a setting which differs from the one of this study.

${ }^{5}$ An interesting rationale for an optimal level of outside equity in the capital structure of firms is provided by Jensen and Meckling (1976).

${ }^{6}$ The terms entrepreneur and project are used interchangeably.

${ }^{7}$ For a given contract note that $\mathrm{W}_{\mathrm{i}}^{\mathrm{f}}=\mathrm{W}^{\mathrm{f}}$, for all $\mathrm{i}$, since $\mathrm{R}_{\mathrm{i}}^{\mathrm{f}}=\mathrm{R}^{\mathrm{f}}$.

${ }^{8}$ Utilities are assumed not to be state-dependent.

${ }^{9}$ In this model, if projects were ranked by the first-order stochastic dominance, i.e. if investment projects differed in ability, de Meza and Webb (1990) would be obtained and different results would follow. More precisely, capital market failure would imply overinvestment with pooling equilibrium.

${ }^{10}$ This assumption makes sense because projects involve risk. With this condition, in bankruptcy states the bank collects an amount which falls short of the value needed to compensate for the total cost of outside finance required in a project.

${ }^{11}$ Historical examples justifying the model of this section can also be advanced. For instance, in the past, in certain countries such as Germany and Japan, large banks played an important role in the provision not only of loan finance but also of equity finance to firms for the purpose of industrial expansion. In this context, it is interesting to quote Hellwig: "During certain periods, especially prior to 1873 , German companies obtained substantial amounts of equity finance. However, the shares (were) held by banks or by clients (...) acting on the bank's advice, so in many respects, banks were as much involved in equity finance as in loan finance. While share markets (in Germany) were organized, they were certainly not anonymous and free for all as the theoretical models would have it" (1990, p. 41).

${ }^{12}$ With lemma 1 , an additional assumption on $\alpha$ will be imposed.

${ }^{13}$ Since $\mathrm{F}>\mathrm{K}-\mathrm{W}_{0}, \varphi \mathrm{R}^{\mathrm{f}}+(1-\varphi) \mu>(1+\rho)\left(\mathrm{F}+\mathrm{W}_{0}\right)$ and so there is an interval of value of $\bar{\alpha}$ near $\varphi$ such that $\gamma$ will exist at any such $\bar{\alpha}$. But if $\bar{\alpha}$ were close enough to 1 , $\bar{\alpha} \mathrm{R}^{\mathrm{f}}+(1-\bar{\alpha}) \mu<(1+\rho)\left(\mathrm{F}+\mathrm{W}_{0}\right)$ and $\gamma$ might not exist.

${ }^{14} \mathrm{It}$ is worth mentioning that a sufficient condition for the domination of contract $\mathrm{P}$ over contracts $(\mathrm{A}, \mathrm{S})$ is that the low-risk category must prefer $\mathrm{P}$ to $\mathrm{S}$. For instance, it is possible to have another different configuration of curves such that the high-risk entrepreneurs prefer $\mathrm{A}$ to $\mathrm{P}$ but the less risky ones prefer $\mathrm{P}$ to $\mathrm{S}$. However, it could easily be shown that in this case Proposition 3 is still valid.

${ }^{15}$ For a more developed explanation see Ibrahimo (1993).

${ }^{16}$ Throughout the analysis it has been assumed that $\mathrm{W}_{0}<\mathrm{K}$. However, the relaxation of this assumption may not change the results of the model, since the demand for outside finance (debt plus outside equity) implies risk sharing. See Ibrahimo (1993). 


\section{REFERENCES}

Bester, H. (1985). Screening vs. rationing in credit markets with asymmetric information. American Economic Review, 75, pp. 850-5.

De Meza, D., and Webb, D. C. (1987). Too much investment: a problem of asymmetric information. Quarterly Journal of Economics, 102, pp. 281-92.

De Meza, D., and Webb, D. C. (1990). Risk, adverse selection and capital market failure. Economic Journal, 100, pp. 206-14.

Gale, D., and Hellwig, M. (1985). Incentive-compatible debt contracts: the one-period problem. Review of Economic Studies, 52, pp. 647-64.

Hellmann, T., and Stiglitz, J. E. (2000). Credit and equity rationing in markets with adverse selection, European Economic Review, 44, pp. 281-304.

Hellwig, M. (1990). Banking, financial intermediation and corporate finance. in

Giovannini, A. and Mayer, C. (eds.), European Financial Integration, Cambridge University Press, Cambridge, England.

Hillier, B., and Ibrahimo, M. V. (1992). The performance of credit markets under asymmetric information about project means and variances. Journal of Economic Studies, 19, pp. 3-18.

Hillier, B., and Ibrahimo, M. V. (1993). Asymmetric information and models of credit rationing. Bulletin of Economic Research, 45, pp. 271-304.

Ibrahimo, M. V. (1993). The Economics of Credit Markets: Theory and Evidence. D. Phil dissertation, York University, England.

Jaffee, D., and Russel, T. (1976). Imperfect information, uncertainty and credit rationing. 
Quarterly Journal of Economics, 90, pp. 651-66.

Jensen, M., and Meckling, W. (1976). Theory of the firm: managerial behaviour, agency costs, and capital structure. Journal of Financial Economics, 3, pp. 305-60.

Keeton, W. R. (1979). Equilibrium Credit Rationing, Garland Publishing Inc., New York, USA. Leland, H., and Pyle, D. (1977). Informational asymmetries, financial structure and financial intermediation. Journal of Finance, 32, pp. 371-87.

Modigliani, F. and Miller, M. H. (1958). The cost of capital, corporation finance, and the theory of investment. American Economic Review, 48, pp. 261-97.

Ross, S. (1977). The determination of financial structure: the incentive signalling approach. Bell Journal of Economics, 8, pp. 23-40.

Rothschild, M., and Stiglitz, J. E. (1970). Increasing risk I: a definition. Journal of Economic Theory, 2, pp. 225-43.

Rothschild, M., and Stiglitz, J. E. (1976). Equilibrium in competitive insurance markets: an essay on the economics of imperfect information. Quarterly Journal of Economics, 80, pp. 628-49.

Stiglitz, J. E. (1988). Why financial structure matters. Journal of Economic Perspective, 2, pp. 121-6.

Stiglitz , J. E., and Weiss, A. (1981). Credit rationing in markets with imperfect information. American Economic Review, 71, pp. 393-410.

Williamson, 0. (1988). Corporate finance and corporate governance. Journal of Finance, 43, pp. 567-591.

Williamson, S. (1987). Financial intermediation, business failures, and real business cycles. Journal of Political Economy, 95, pp. 1196-1216. 
FIGURE 1

Offer curves of a bank

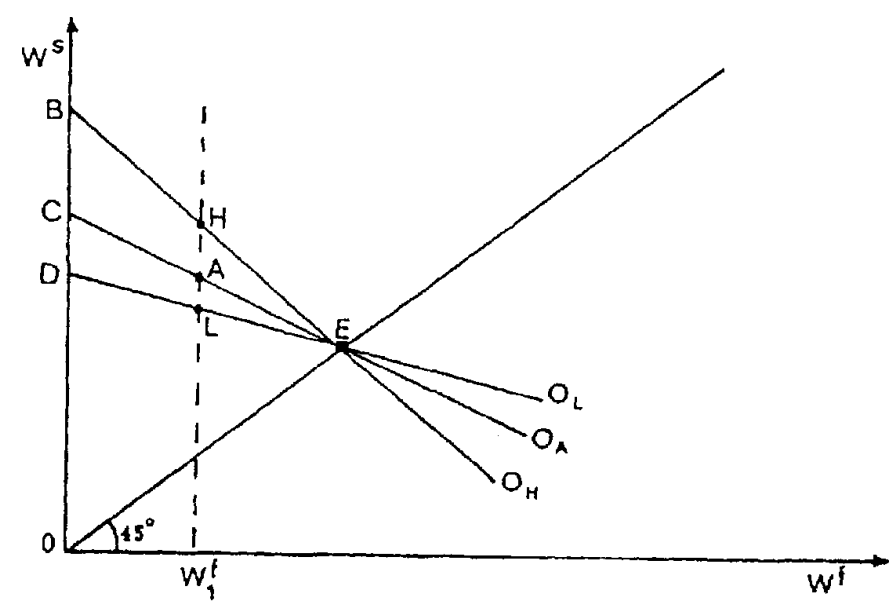

F I G U RE 2

Equilibrium with no private information

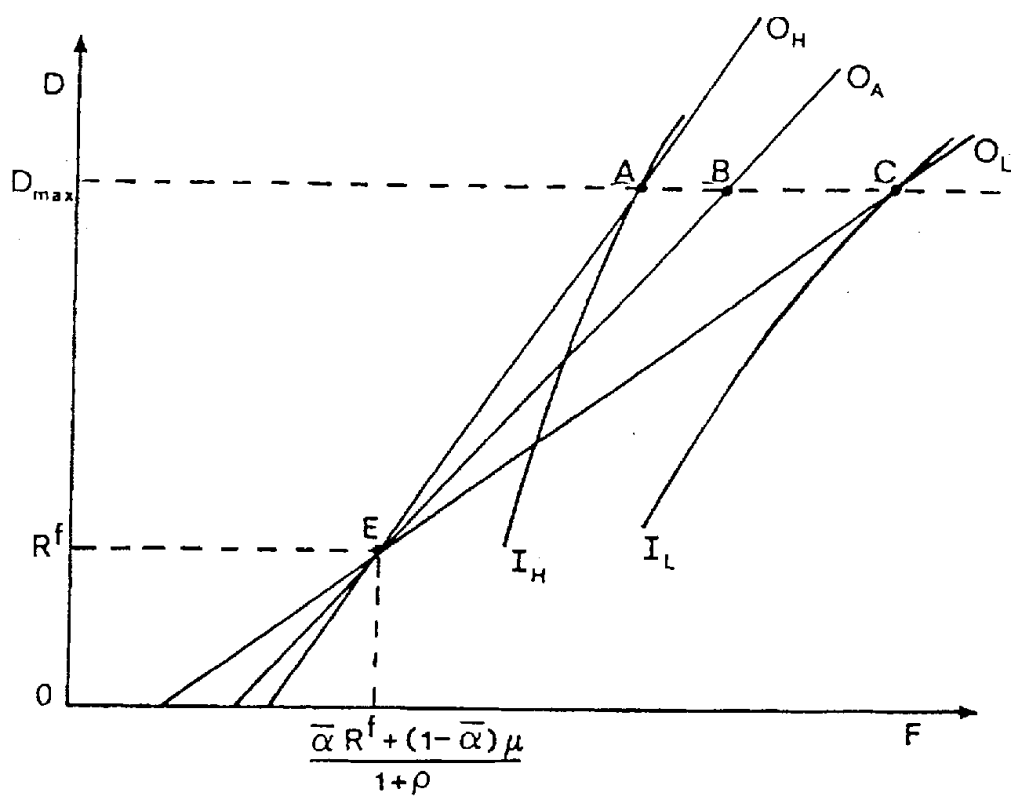


FIGURE 3

Non-existence of equilibrium

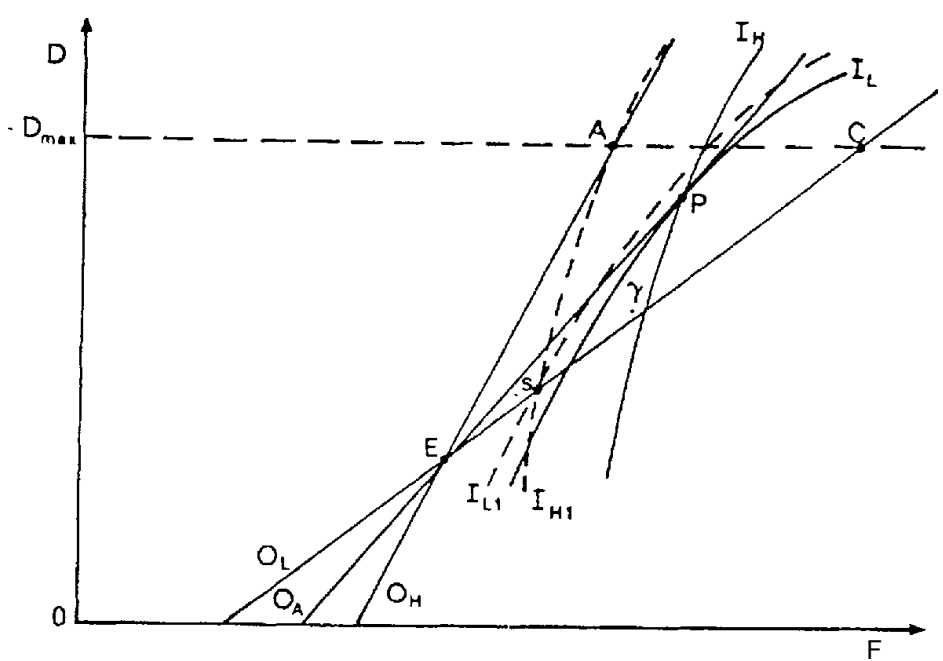

F I G U R E 4

Separating equilibrium

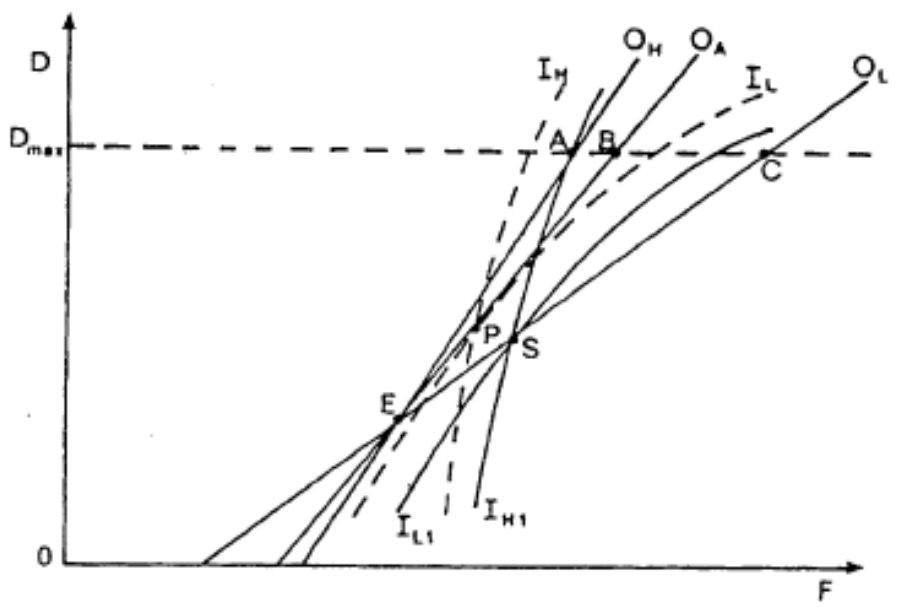

